\title{
Racial Identity and the Patterns of Consolation in the Poetry of Robert Hayden*
}

\begin{abstract}
John S. Hatcher
* This article was first delivered as a paper at the conference "Words in the Time: A Celebration or Robert Hayden's Poetry," which was held at the University of Michigan, Ann Arbor, Michigan, February 22-25, 1990. This was the first conference dedicated to Robert Hayden's poetry.
\end{abstract}

\begin{abstract}
Few critics have given Robert Hayden’s poetry the careful reading it deserves and demands. As a result, his work has almost inevitably been misinterpreted and misunderstood. A more significant result is that the dramatic tension in his work has often been mistaken for personal ambivalence and confusion with regard to both his ethnic identity and his beliefs as a Bahá'í. However, an accurate and careful reading of his work in light the unmistakably clear allusions in poetry to his beliefs as a Bahá'í reveal neither ambivalence nor confusion, but a clear pattern of consolation that unites both of these points of view.
\end{abstract}

\section{Résumé}

La poésie de Robert Hayden a malheureusement reternu l'attention de peu de critiques. En conclusion, son oeuvre a été mal interprétée et mal comprise. De plus, la tension dramatique de son oeuvre a souvent été prise pour de l'ambivalence ou de la confusion due à son identité éthnique et à son adhésion à la foi bahá'íe. Cependant, une lecture exacte de son oeuvre mettant en valeur les allusions sans équivoque de sa poésie à ses croyances bahá'íes ne révèle aucune ambivalence ni confusion mais au contraire un modèle précis de consolation qui réunit ces deux points de vue.

\section{Resumen}

Pocos críticos le han dado a la poesía de Robert Hayden la lectura cuidadosa que merece y exige. Por lo tanto, sus obras han sido, casi inevitablemente, mal interpretadas y mal comprendidas. Un resultado aún mas significativo es que la tensión dramática en sus obras ha sido frecuentemente tomada erróneamente como ambivalencia personal y estado de confusión relativo tanto a su identidad étnica como a sus creencias como bahá'í. Sin embargo, una lectura precisa y cuidadosa de sus obras a la luz de alusiones claras e inequívocas en su poesía referente a sus creencias como bahá'í, no evidencian ni ambivalencia ni confusión, sino un modelo claro de consolacíon que unifica ambos puntos de vista.

Tn discussing his response to an idealogue of the 1960s civil rights movement who had criticized his poem "Ballad 1 of Remembrance" because in it the persona finds respite from racial tensions by conversing with a white poet, Robert Hayden said that at first he tried to explain what the poem really meant: "Then I got mad. If you read carefully_and I write carefully_you don't have to question me about anything” (quoted in Hatcher, From the Auroral Darkness 89).

It is unfortunately the case that during Hayden's life few readers or critics gave his poems the careful reading they deserve and demand. As a result his work was almost inevitably misinterpreted and misunderstood so that the very courage he displayed was often perceived as weakness, and the lonely outpost he occupied in defense of art became lonelier still. Perhaps a more significant result, however, was that the tension in his work, which alone produces worthwhile art, was often mistaken for personal ambivalence and confusion with regard to both his ethnic identity and his beliefs as a Bahá'í.

The first of these misconceptions was that his demand to be considered a poet who happened to be Black and not a "Black poet" was tantamount to a rejection of his own racial identity and the noble efforts of the civil rights struggle. Though Hayden's stand has been somewhat redeemed by more recent assessments of his life and work, the issue bears further clarification.

At a time when many Black writers believed that their best course of action for assisting the civil rights movement was to use their art as a political weapon, Hayden, who had long before in the 1930s come to distrust art as polemic, forcefully denounced the easy categorizing of artists according to racial or ethnic considerations, in spite of the fact that some of his best poems were tightly focused on the history of racial injustice in America: 
"I have said this until I almost think I'll choke and fall over backwards," thus began a visibly disturbed Robert Hayden addressing himself to the argument as to whether one is a Negro poet or, as Hayden insists, "a poet who happens to be a Negro." Reading lines from Yeats, Hayden solemnly commented, "I didn't have to be Irish to love those lines." (Quoted in Hatcher, From the Auroral Darkness 37)

No doubt, Hayden would have agreed that Yeats might have found it considerably more difficult to write the lines without having been Irish (just as Auden, Hayden's own mentor at the University of Michigan, had noted how "mad Ireland hurt [Yeats] into poetry"). But that was not the issue. Hayden was not protesting the methods by which the poet necessarily wrests themes and images from personal experience. He was instead resisting the tendency to abandon the criterion for good poetry on the one hand, principles which he felt transcended questions of ethnicity, or on the other hand lumping poets together because of ad hominem considerations.

It was a stand he had taken quite thoughtfully and explicitly twenty years before in the 1946 preface to the Counterpoise poems:

As writers who belong to a so-called minority, we are violently opposed to having our work viewed, as the custom is, entirely in the light of sociology and politics, to having it overpraised on the one hand by those with an axe to grind or with a conscience to salve, to having it misinterpreted on the other hand by coterie editors, reviewers, anthologists who refuse us encouragement or critical guidance because we deal with realities we find it neither possible nor desirable to ignore.... (Quoted in Hatcher, Auroral 22)

He concluded with the affirmation, "We believe in the oneness of mankind and the importance of the arts in the struggle for peace and unity.”

This determination to have his work judged according to the highest critical standards irrespective of racial considerations also reflected his staunchly held belief that if all Black writers could be lumped together by critics, they could also be more easily dismissed and chucked into some literary ghetto. In short, it was not for lack of racial pride he took this stand, but because of it.

Along these same lines, Hayden once remarked that there is "tendency to regiment Afro-American artists and to feel that they should all say the same thing.... But we are as complex and as various as any other people" (quoted in Hatcher, Auroral 71). In a more vehement mood he asked rhetorically, "Are we to be told what to write about and how to write? Are we to be restricted in our choice of subjects?" (Quoted in How I Write 184). In perhaps his most resounding statement on the subject, he asserted, "I am alive in my time-alive in the world. I respond to everything around me. I have my own inner personal struggles which have nothing to do with race ...” (quoted in Hatcher, Auroral 71).

For Hayden, this issue of racial categorization was inextricably linked to his more encompassing views as a Bahá'í that the long-term solution to racism was to be found in striving for a more inclusive identity, not in the achievements of one faction of humanity at the expense of or even in terms of another:

The fact that I am a Bahá'í and believe in the oneness of mankind became known in the 60's. My philosophy, then as now, was that the struggle to be a human struggle, black and whites cooperating to remove evils as human beings rather than doing it separately as races. (Quoted in Hatcher. Auroral 89-90)

In addition to racial identity, there is a second source of perceived tension in Hayden's poetry - the ostensible disparity between his largely optimistic views as a Bahá'í regarding this period in human history as effecting the fulfillment and redemption of human history and the often stark images of injustice, violence, grief, and uncertainty that seem to pervade so many of Hayden's most powerful poems. This apparent conflict between enunciated belief and the poet's art evoked at least three sorts of negative reaction.

The most prominent and possibly the most unfortunate response to this perceived tension has been the reaction among those critics who consign Hayden's poetry to historical context, viewing his work circumscribed by or confined to personal modes and themes. For them, his poems are no more than extensions of biographical factto study Hayden's poetry is to study Hayden. Consequently, these same readers interpreted the juxtaposition of implicit hope with existential angst as reflecting Hayden's ambivalence about his beliefs. Chief among such critics is Pontheolla Williams, authorized biographer of Hayden. ${ }^{1}$

A second sort of reaction has come from some of Hayden's fellow Bahá'ís, most of whom were only vaguely aware of his work and a good many of whom might have had trouble understanding what practical benefit could be derived from so esoteric an art at this crucial juncture in history unless somehow that gift were used directly and overtly in promulgating the Bahá'í ideals. That is, the Bahá'í teachings portray this historical period as 
heralding the long-awaited advent of a planetary consciousness to replace ancient prejudices and provincialism; therefore, the focus of energy is most often aimed at attempting to help humanity become aware of this imminent metamorphosis or else at going about the practical business of establishing Bahá'í communities wherein the administrative framework for a world commonwealth can be established and the principles of world unity exemplified. Naturally, such heady aspirations are viewed by as taking precedence over less urgent affairs, a conviction that would seem to be confirmed by statements in the writings like the following:

Therefore, now is the time that you may divest yourselves from the garment of attachment to this phenomenal realm, be wholly severed from the physical world, become angels of heaven and travel and teach through all these regions. ('Abdu'l-Bahá, Tablets of the Divine Plan 11)

As an example of how this perspective affected the appreciation of Hayden’s work, one Bahá'í who was to introduce him at a poetry reading asked what "Bahá'í" work he did. In a similar episode, a young woman escorting Hayden to another reading informed him that she too once wrote poetry but gave it up to serve the Bahá'í Faith. ${ }^{2}$ In general Hayden was bemused more than hurt by such attitudes, though one of Hayden's fellow editors of World Order Magazine wrote me the following regarding the 1990 "Words in the Mourning Time" commemoration of Hayden at the University of Michigan conference on Hayden:

I cannot help thinking of the many times that Robert Hayden told me, when he let his hair down, about how little he felt the Bahá'í community understood the work he did. He must be thrilled, as he watches from another realm, the unfolding of the appreciation of his talents. (Betty Fisher, letter to the author, 13 December 1989)

In a 1976 interview Hayden acknowledged that he himself had, at a crucial point in his career, directly confronted the relevancy of his fit to his beliefs as a Bahá'í:

I sat in my front room one day when I was still teaching at Fisk University and was filled with a sense of cold, almost inexpressible horror, because something sort of swept over me; "You are not really dealing with reality. Everything you are doing is false because you don't really see the connection between what you say you believe and what you are doing as a writer.” It was naturally a horrifying experience.

After that, I guess I began to try to see what the relationship was, and today I feel very comfortable in that. It lies behind everything I do. Indeed, when I was less sophisticated in my outlook, I thought that the only way I really could serve [the Bahá'í Faith] was by writing religious poems, but later on as I pondered what Bahá'u'lláh said about the role of the artist, I began to realize that if you really had the new spiritual orientation, just about anything you did could be of service. (Quoted in Hatcher, Auroral 28)

In a more general sense, Hayden often observed that "poetry, all art, it seems to me is ultimately religious in the broadest sense of the term. It grows out of, reflects, illuminates our inmost selves.... It doesn't have to be sectarian or denominational” (quoted in O’Brien, Interviews with Black Writers 115).

A third source of negative reaction to Hayden's relationship between his poetry and his religious beliefs came from some of the few critics careful enough to note the crucial function of Hayden's allusions to the Bahá'í Faith in his poetry and who condemned these as inappropriate. For example, Robert Greenberg stated:

Since the general audience does not share Hayden's sentiments about this prophet, his faith seems undemonstrated in the poem, an imposition on the reader. Hayden's immersion in the universalist content of Bahá'u'lláh's message may have obscured from him the fact that to Western readers it seems not so much humane and unifying as strange and sectarian. (American Writers 371)

So it was that in spite of Hayden's persistent and forceful statements elucidating a basis for his attitude regarding both areas of tension in his poems, his pronouncements could hardly restrain perceptions to the contrary, particularly since readers of his work could not have been aware of the poet's personal views. To resolve questions about the poet's work, the reader must turn to the poems themselves.

What most readers have not understood sufficiently well, if at all, is the essentially symbolic nature of Hayden's work, not simply because he affirmed that he was a symbolist poet, but because there are unavoidable and consistently employed figurative images beneath the beguilingly accessible surfaces of his poems to confirm this 
fact. Consequently, if we wish to resolve these two apparent conflicts or tensions in Hayden's work, it is imperative that we examine creatively and intelligently the individual tropes and patterns of images in Hayden's poems.

While I have in From the Auroral Darkness (267-80) discussed more amply the consistent quality of his symbols and images as well as the way in which many of them recur with great frequency, it is significant to note here that the primary reason most readers and critics failed to feel the weight of the responsibility to discover these other levels of meaning in Hayden's work is that so many his poems draw on personal experience as metaphorical vehicle or referent. Wilburn Williams, Jr. noted the likelihood of this explanation when he observed how Hayden's symbols, unlike the more objective tropes of Yeats, Pound, or Eliot, often employ the personal anecdote as correlative for universal themes. Williams suggests that instead of the "objective correlative" of Eliot's work, Hayden has produced a "subjective correlative" ("Covenant of Timelessness" 67).

Regardless of why the symbolic nature of Hayden's art has been neglected, we can, even with a cursory examination of his work, discover a resolution to both areas of perceived conflict in his poetry. For example, among his poems that treat racial themes, or at least that derive their impetus from images tightly focused on racial identity and Afro-American history, we can detect definable and progressive stages of reconciliation and redemption. In some longer works, the entire pattern is evident. In "Middle Passage," "Runnagate Runnagate," "El Hajj Malik ElShabazz," and "Words in the Mourning Time," one can discover a process that closely parallels the paradigm of history as the emergence of a universal human identity and consciousness that will transcend, though not disregard or disdain, considerations of race and nationality. Bahá'u'lláh states:

The tabernacle of unity hath been raised; regard ye not one another as strangers. Ye are the fruits of one tree, and the leaves of one branch. We cherish the hope that the light of justice may shine upon the world and sanctify it from tyranny. (Gleanings 218)

At the same time, the writings also affirm that achieving this just condition will necessitate, especially in America, coming to terms with the most significant deterrent to that resolution, the "most challenging issue" of racism:

As to racial prejudice, the corrosion of which, for well nigh a century, has bitten into the fiber, and attacked the whole social structure of American society, it should be regarded as constituting the most vital and challenging issue confronting the community at the present stage of its evolution. (Shoghi Effendi, The Advent of Divine Justice 33-34)

Fully aware of and in accord with these and other teachings about racial identity in relation to the emergence of a more encompassing and transcendent identity—humankind as world citizens-Hayden is able to hint at the obstacle to this process that racism imposes, hint at the ultimate escape from the clutches of this evil, and yet refrain from becoming dogmatic, doctrinaire, or didactic. He manages to achieve this by employing symbols, by constructing a pattern of images, and by distributing the parts of this vision among many poems rather than by attempting to incorporate the entire thought into a single piece.

For example, the first part of this pattern might be the sense of belonging and identity from a recollected past, the images of which serve as a haunting reminder of what is currently missing. On the personal level, it might be the persona's nostalgia for the ghetto neighborhood, Paradise Valley. In the poems that treat Afro-American history, it is frequently the vague but powerful nostalgia for the African identity, which has been so vilely abused and oppressed. The integrity of that identity may be a thing of the past, but the recollection of it exercises great power over us, not only in terms of nostalgic recollection but also in defining exactly the sort of integrality that has been lost. In “O Daedalus, Fly Away Home,” after asking “Do you remember Africa?” the disembodied voice of the slave concludes the means of his return to a recollected condition of wholeness:

Night is a mourning juju man

weaving a wish and a weariness together

to make two wings.

\section{O fly away home fly away}

(Collected 55)

This use of flight as a symbol of progress towards identity and fulfillment of inherent purpose is used repeatedly in Hayden's poetry. It can be observed implicit in the ghetto images in "Summertime and the Living ..." when the "harshened” elders sit on "broken steps," symbols of their own fractured dreams of ascent, while they watch 
Jack Johnson in his diamond limousine

set the ghetto burgeoning

with fantasies

of Ethiopia spreading her gorgeous wings.

(Collected 39)

Sometimes the images of lost identity relate to bewilderment or dissociation more than to a specific recollection of what has been taken away. On the personal level, the poet/persona enunciates confusion regarding his own past in "Names," and frequently throughout Hayden's poems we encounter thoroughly intriguing characters who emerge resilient even though their sense of themselves has been lost or violated. "Aunt Jemima of the Ocean Waves" and "The Ballad of Sue Ellen Westerfield" are both emblematic of this heroic persistence. Whereas the prisoner in "Soledad" is bereft of hope: "His fears and his unfinished self/ await him down in the anywhere streets" (Collected 71).

A second stage in this pattern of racially oriented symbols relates to images of violence, rage, and rebellion. Sometimes the violence is on the part of the oppressed, as in "The Ballad of Nat Turner" or in the first part of his poem on Malcolm X ("El Hajj ..."), but more often the images surround further oppression and dehumanization in poems like "Night, Death Mississippi" and "Figure of Time" where gross physical desecration symbolizes an array of more subtle injustices. Physical violence and oppression, as associated with this loss of identity, are also implied in powerfully understated scenes from "Middle Passage" where African tribesmen leap to death in shark-infested waters in preference to slavery. In "Words in the Mourning Time," part vi, Hayden presents a collage of violence as endemic to our own age:

$$
\begin{aligned}
& \text { Lord Riot } \\
& \text { naked } \\
& \text { in flaming clothes } \\
& \text { of anger's } \\
& \text { carousals } \\
& \text { (Collected 95) }
\end{aligned}
$$

But in some individual poems and certainly in the overall pattern of poems dealing with racism and AfroAmerican themes, there is a third stage, a vision of possibilities, of progress towards justice, identity, what Hayden calls "humanness." This sense of the future is also based on or at least confirmed by Hayden's beliefs as a Bahá'í. For example, the writings forthrightly portray this contemporary period as a wrenching transition similar to the pangs of childbirth:

A tempest, unprecedented in its violence, unpredictable in its course, catastrophic in its immediate effects, unimaginably glorious in its ultimate consequences, is at present sweeping the face of the earth. Its driving power is remorselessly gaining in range and momentum. Its cleansing force, however much undetected, is increasing with every passing day. (Shoghi Effendi, The Promised Day is Come 3)

Therefore, while much of Hayden's poetry seems focused on existential bewilderment, he also has abundant indices to a future condition in which humanity has been cleansed of prejudice and provincialism and has achieved a state of natural nobility.

Often the symbol of this future growth is a literal journey. In "Runnagate Runnagate" it is the escape to freedom, though in the poem the journey to freedom is never completed. In "Middle Passage," Hayden depicts the passage through slavery as a "voyage through death / to life upon these shores" (Collected 48), also an unfinished process. But in a few poems, Hayden lets us glimpse that future possibility. In "El Hajj ...” Hayden alludes powerfully to Malcolm X's pilgrimage to Mecca where the former advocate of violent revolt envisioned a transcendent identity and "fell upon his face before / Allah the raceless in whose blazing Oneness all / were one ..." (Collected 89).

Malcolm X is not the only Hayden character portrayed as having emerged from the caldron of racism redeemed, detached, and prefiguring the redemption of humankind as a whole and glorying in achieved humanity. In celebrating Frederick Douglass, for example, Hayden describes the hero as "superb in love and logic," as one who heralds a time when freedom "belongs at last to all" and where "none is lonely, none hunted, alien ..." (Collected $62)$. 
We begin to see, then, that the resolution to the tension surrounding Hayden's treatment of racial identity is ultimately inextricably linked to Hayden's beliefs as a Bahá'í. In short, the first source of perceived conflict is integral to the second source of tension-the apparent disparity in Hayden's poetry between his portraiture of the inexhaustible nature of human perversity and his allusions to the vision of human history as a process of fostering an “ever-advancing civilization” (Bahá’u’lláh, Gleanings 215).

One rationale for the alliance of these two themes is the fact that Hayden clearly extrapolates from AfroAmerican history a parallel to the paradigm of human history as whole. The key to the analogy is found in the notion of this present age as a period of necessarily violent transition. The end result of this process, Bahá'ís believe, will be the establishment of a universal peace and a world civilization. However, caught between identities, humanity can currently find little comfort: outworn are no longer consoling, and the promise of future transformation does not alleviate present pain, suffering, and alienation. For a number of reasons, among them being Hayden's own personal groping to discover a sense of self, Hayden chose to focus marc forcefully on enunciating the terror of transition than on basking in the joy of progress towards that long-awaited shore.

Nevertheless, rarely are even his most brutal poems without some hope, without an important sign or symbol of that future light shining in the darkness of our terror and despair. Almost inevitably the basis for this hope converges on his allusions to the Bahá'í Faith. In "Full Moon” the moon's light is "made holy" by spreading its "radiance on the exile's path/ of Him who was The Glorious One" (Collected 7), ${ }^{3}$ an explicit reference to Bahá'u'lláh as the source of the reflected light of God's power and attributes. The poem "Dawnbreaker" also employs the symbol of light as heralding enlightenment or a new day both with the lighted candles stuck in the martyr's wounds as symbolic of the fire of faith and in the title, which employs the appellation of the early Bahá'í who were martyred by the Islamic clergy. ${ }^{4}$

In "From the Corpse Woodpiles ...," a stark image of the Nazi holocaust, the persona flees "Through target streets" until he finds ironic consolation in the suffering he sees in Bahá'u'lláh

cold cloacal cell

where He, who is man beatified

And Godly mystery, lies chained, His pain our anguish and our anodyne.

(Collected 46)

In "Bahá'u'lláh in the Garden of Ridván” the Prophet paces in the night as "undiscovered suns/ release their light" signaling that nature is already giving clues to the incipient transformation of human society.

On a more subjective level, the fearful speaker in "The Broken Dark" prays as he feels himself in "God's laser light": "O Healing Spirit. / Thy nearness our forgiving cure" (Collected 69). In "The Prisoners" the persona visits prisoners to read his poems for them ("poems I hoped were true") and "shared reprieving Hidden Words" (Collected 159)—-the Hidden Words of Bahá'u'lláh being the first major work revealed by Bahá'u'lláh. ${ }^{6}$

Sometimes the allusions to the vision of history are less obvious. In "The Wheel," Hayden employs a figural allusion to the notion of progressive revelation. In "Night Blooming Cereus," the persona and his wife await in the night with mystic anticipation the imminent bloom of the exotic flower (Collected 114). In the thinly veiled Platonism of "Traveling through Fog" Hayden succinctly portrays physical reality as a hazy prefiguring of spiritual reality: ${ }^{7}$

Behind us, beyond us now is phantom territory, a world abstract as memories of earth the traveling dead take home. Between obscuring cloud and cloud, the cloudy dark ensphering us seems all we can be certain of. Is Plato's cave.

(Collected 122) 
Perhaps the most forceful and certainly the most direct poem dealing with the Bahá'í concept of an imminent resolution to personal and collective history is "Words in the Mourning Time." In the first part of this poem, the speaker says he grieves even though intellectually he knows

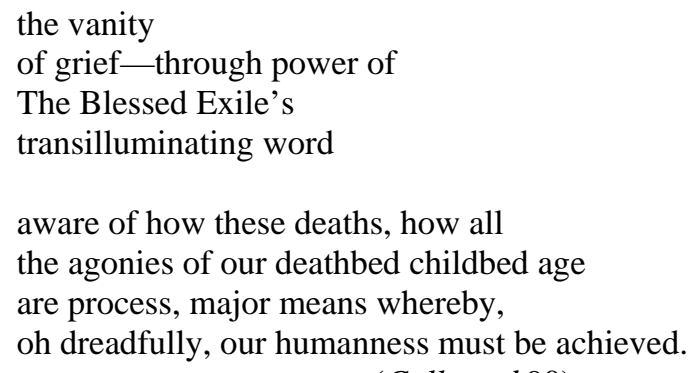

(Collected 90)

But as direct and clear as are the allusions to Hayden's beliefs about the future in this passage, the succeeding sections proceed to catalogue contemporary violence until, one senses, the implicit conviction of the first part has become dissipated, much the same sort of diminution of faith as Herbert's persona exemplifies in "The Collar." But like the rebellious cleric in Herbert's poem, the persona in Hayden's poem is restored to conviction in the final section as he recites the daily obligatory prayer: ${ }^{8}$

I bear Him witness now-

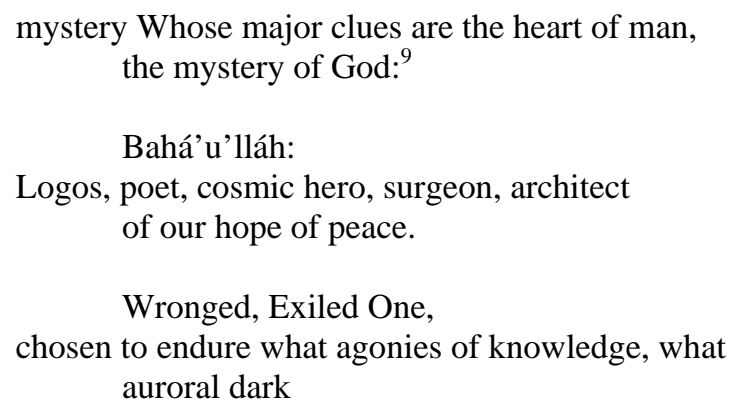

(Collected 99)

Hayden thus alludes to the Bahá'í teachings not as antithetical to the agonies of present social conditions, but as the hope in the "dead of night" that heralds the "renewal of/ the covenant of timelessness" and proclaims the "advent of splendor joy/ alone can comprehend" (Collected 99).

The setting may be in the darkness of night, but it is an "auroral" dark, and this oxymoronic image conveys perfectly the paradox of this transition as Hayden perceived it. Therefore, the poem concludes with the statement that only in the vision of history as portrayed in the writings of Bahá'u'lláh will the ultimate meaning to and redemption of our present conditions be discovered:

I bear Him witness now:

toward Him our history in its disastrous quest

for meaning is impelled.

(Collected 100)

Of course, however assured Hayden may have been as an individual that present images of chaos are indices to the birth of human fulfillment or, further, that the shadowy world of physical forms prefigures more perfect spiritual reality (as the stranger in "Theme and Variation" asserts), he seems to have felt his purpose as artist to be in enunciating the perplexing enigmas of living in this chaotic age of transition. Possibly he even felt it his calling to minister artistically to the afflicted and bereft, perhaps even to those like himself who, though anticipating the bright future, are aware that this is also a proper time for mourning.

So it is that the voice in Hayden's poetry often cries out in the midst of our collective labor, coaching our common pain, helping us enunciate our shared confusion and consternation even while pointing to the glimmer of the morning light in our present darkness. Perhaps he saw his function as artist to help us recognize how, like 
Arachne in his poem "Richard Hunt's' Arachne'," all of us are caught in "the moment's centrifuge of dying/ becoming," our eyes "brimming with horrors/ of becoming," our mouth shaping "a cry it cannot utter,"(Collected 113) and so he tries to utter it for us. In this sense there is indeed a palpable tension in Hayden's poetry, but it is not the grating of reality against pious hope. It is, rather, what Hayden perceived to be the building action in the plot of our collective human drama as we near climactic reversal in order to achieve dénouement.

\section{Notes}

1. Williams's biography of Hayden is to be published by University of Illinois Press.

2. These and other incidents, as well as a larger discussion of how this dilemma affected Hayden, are discussed in From the Auroral Darkness 71ff.

3. Bahá'u'lláh was exiled four successive times to remove Him away from influencing the people of Persia, and He is sometimes alluded to in the Bahá'í writings as “The Blessed Exile.” Likewise, his title "Bahá'u'lláh” translates to "The Glory of God."

4. This poem about a particularly bizarre torture of a Bahá'í, Hájí Sulaymán as described in Shoghi Effendi, God Passes By 77-78. See also Nabil's The Dawnbreakers 617-18.

5. This brief prayer is sometimes used a greeting by Bahá'ís, replacing for them the phrase similarly used by Muslims “Alláh’u’Akbar.” Both mean “God is most glorious” or "God of the Greatest Glory.”

6. Revealed in the early 1850s, this work purports to be a poetic synthesis of the essential spiritual verities of past revelations.

7. For an ample discussion of the Platonic perspective of reality in relation to perspective, see John S. Hatcher, The Purpose of Physical Reality: The Kingdom of Names $27 \mathrm{ff}$.

8. Sometimes called the "Short Obligatory Prayer" or the "Noonday Prayer," the entire prayer can be found in Bahá'í Prayers 4.

9. 'Abdu'l-Bahá was called Sirru'lláh ("the Mystery of God”) as an indication of his station as Exemplar of the Bahá’í Faith. Shoghi Effendi, The World Order of Bahá'u’lláh 134.

\section{Works Cited}

‘Abdu’l-Bahá. Tablets of the Divine Plan. Wilmette: Bahá'í Publishing Trust, 1959.

Bahá'í Prayers. 3d ed. Wilmette: Bahá’í Publishing Trust, 1985.

Bahá'u'lláh. Gleanings from the Writings of Bahá'u'lláh. Trans. Shoghi Effendi. 2d ed. Wilmette: Bahá'í Publishing Trust, 1976.

—. The Hidden Words of Bahá'u'lláh. Wilmette: Bahá'í Publishing Trust, 1939.

Fisher, Betty J. Letter to John S. Hatcher. 13 December 1989.

Greenberg, Robert M. American Writers: A Collection of Literary Biographies. New York: Charles Scribner’s Sons, 1982. 
Hatcher, John S. From the Auroral Darkness: The Life and Poetry of Robert Hayden. Oxford: George Ronald, 1984. . The Purpose of Physical Reality: The Kingdom of Names. Wilmette: Bahá'í Publishing Trust, 1987.

Hayden, Robert E. Robert Hayden: Collected Poems. Ed. Frederick Glaysher. New York: Liveright Publishing Corporation, 1985.

Interviews with Black Writers. Ed. John O’Brien. New York: Liveright, 1973.

Nabíl-i-A‘zam. The Dawn-Breakers. Ed. Shoghi Effendi. Wilmette: Bahá’í Publishing Trust, 1962.

Shoghi Effendi. The Advent of Divine Justice. Wilmette: Bahá'í Publishing Trust, 1984.

. God Passes By. Rev. ed. Wilmette: Bahá'í Publishing Trust, 1974.

- The Promised Day is Come. Rev. ed. Wilmette: Bahá'í Publishing Trust, 1980.

— The World Order of Bahá'u’lláh. 2d ed. Wilmette: Bahá'í Publishing Trust, 1974.

Williams, Wilburn, Jr. "Covenant of Timelessness," in Chant of Saints: A Gathering of Afro-American Literature, Art and Scholarship. Chicago: University of Illinois Press, 1979. 